\title{
Intervensi Komitmen Organisasional Pada Pengaruh Kepuasan Kerja Terhadap Organizational Citizenship Behavior (OCB)(Studi Dalam Setting Organisasi Kemahasiswaan)
}

\author{
Meika Kurnia Puji Rahayu, Septi Ani Qurdiana \\ Prodi Manajemen, FEB, Universitas Muhammadiyah Yogyakarta
}

This research aims to analyze the role of organizational commitment in intervening the influence of job satisfaction toward organizational citizenship behavior (OCB), particularly in student organizational setting. Research subject is member of Himpunan Mahasiswa Manajemen (HIMAMA), a student organization in the Dapertment of Management, Faculty of Economics and Business, Universitas Muhammadiyah Yogyakarta. Sample was determined through purposive sampling, yielded 102 respondents. Data was collected using questionnaires, and then analyzed using Structural Equation Modeling (SEM) with AMOS software. The research findings confirm that organizational commitment acts as intervening variable on the influence of job satisfaction toward OCB.

Keywords: job satisfaction, organizational commitment, Organizational Citizenship Behavior (OCB), intervening

OPEN ACCESS

ISSN 2528-4649 (online)

ISSN 2338-4409 (print)

${ }^{*}$ Correspondence:

Received: November 20, 2019 Accepted: February 17, 2020 Published: March 4, 2020

Citation:

Kurnia Puji Rahayu M and Ani

Qurdiana S (2020) Intervensi

Komitmen Organisasional Pada

Pengaruh Kepuasan Kerja Terhadap

Organizational Citizenship Behavior

(OCB)(Studi Dalam Setting

Organisasi Kemahasiswaan).

Intervensi Komitmen Organisasional

Pada engaruh Kepuasan Kerja

Terhadap Organizational Citizenship Behavior (OCB)(Studi Dalam Setting

Organisasi Kemahasiswaan) . 6:1.

doi: http://doi.org/10.21070/jbmp.v

$6 i 1.445$
Penelitian ini bertujuan untuk menganalisis peran komitmen organisasi dalam mengintervensi pengaruh kepuasan kerja terhadap perilaku warga organisasi (OCB), khususnya dalam pengaturan organisasi siswa. Subjek penelitian adalah anggota Himpunan Mahasiswa Manajemen (HIMAMA), organisasi kemahasiswaan di Departemen Manajemen, Fakultas Ekonomi dan Bisnis, Universitas Muhammadiyah Yogyakarta. Sampel ditentukan melalui purposive sampling, menghasilkan 102 responden. Data dikumpulkan dengan menggunakan kuesioner, dan kemudian dianalisis menggunakan Structural Equation Modeling (SEM) dengan perangkat lunak AMOS. Temuan penelitian mengkonfirmasi bahwa komitmen organisasi bertindak sebagai variabel intervening pada pengaruh kepuasan kerja terhadap OCB.

Keywords: job satisfaction, organizational commitment, Organizational Citizenship Behavior (OCB), intervening

\section{PENDAHULUAN}

Sumber Daya Manusia (SDM) diyakini menjadi kunci sukses perubahan organisasi. Partisipasi yang disertai kemauan dan kemampuan dari masing-masing individu karyawan atau anggota organisasi sangat dibutuhkan untuk keberhasilan perubahan organisasi dalam mencapai tujuannya.

Namun, dukungan SDM pada pencapaian tujuan organsiasi tidak hanya diberikan dengan cara berkontribusi dan mampu menjalankan semua tugas-tugas yang diberikan organisasi 
dengan baik. Lebih dari itu, organisasi juga memerlukan kemauan individu berinisiatif dan mau melakukan pekerjaan-pekerjaan di luar tanggung jawab yang diamanatkan organisasi pada dirinya.

Menurut Aldag dan Resckhe (1997), kontribusi individu yang melebihi tuntutan peran di tempat kerja disebut dengan Organizational Citizenship Behaviour (OCB). Perilaku ini mencakup perilaku seperti membantu orang lain, menjadi sukarelawan untuk kegiatan di luar pekerjaan, dan menegakkan aturan dan prosedur di tempat kerja terlepas dari ketidaknyamanan pribadi tanpa adanya permintaan reward secara formal dari organisasi. OCB diperlukan oleh organisasi karena meningkatkan efektifitas organisasi, terutama dalam membangun aspek-aspek sosial dalam organisasi, seperti komunikasi antar individu dan kesolidan tim atau unit kerja (departemen).

Topik OCB telah mendapat banyak perhatian dalam literatur, dibuktikan dengan banyaknya penelitian mengenai topik ini dengan latar belakang atau setting perusahaan (organisasi berorientasi laba). Namun, tidak banyak (atau bahkan belum ditemukan) penelitian mengenai OCB dalam setting organisasi kemahasiswaan. Padahal, dalam lingkup organisasi kemahasiswaan, organisasi yang tentu saja tidak berorientasi laba dan kebanyakan memiliki sumberdaya (orang dan uang) yang terbatas, perilaku ekstra atau OCB ini sangat diperlukan demi terlaksananya program-progam kerja dan etrcapainya tujuan organisasi. Untuk itu, peneliti memandang bahwa penelitian tentang OCB dalam konteks organisasi kemahasiswaan adalah penting untuk dilakukan.

Salah satu faktor yang sering disoroti sebagai variabel yang memiliki pengaruh signifikan pada terciptanya OCB adalah kepuasan kerja (Dewi \& Suwandana, 2016; Hapsari, 2015; Sambung, 2011). Namun, konsep tersebut dibantah oleh Lestariningtias (2016), yang menemukan bukti bahwa kepuasan kerja tidak berpengaruh langsung terhadap OCB. Dalam hal ini, hasil penelitian Lestariningtias (2016) menunjukkan adanya intervensi dari faktor lain, yaitu komitmen organisasional. Kesenjangan yang teridentifikasi dalam penelitian ini adalah kepuasan kerja belum meyakinkan dalam mempengaruhi OCB, apakah berpengaruh langsung ataukah harus diintervensi oleh faktor lain. Tujuan dari penelitian adalah untuk menguji dan menganalisis pengaruh kepuasan kerja terhadap OCB dan peran komitmen organisasional dalam pengaruh tersebut.

\section{KAJIAN LITERATUR}

\section{Organization Citizenship Behavior (OCB)}

Menurut Organ (1988:4) OCB merupakan perilaku individu yang bersifat diskresioner, tidak secara langsung atau eksplisit diakui oleh sistem penghargaan formal, dan dalam lingkup yang lebih besar dapat meningkatkan efektifitas organisasi. Artinya, apabila anggota organisasi melakukan tindakan tersebut (di lua deskripsi pekerjaannya), maka dia mungkin menerima atau tidak menerima penghargaan. Sebaliknya, jika ia tidak melakukan tindakan, maka tidak akan ada hukuman dari organisasi karena perilaku OCB tidak termasuk dalam bagian dari deskripsi tugas formalnya. OCB terdiri dari 5 dimensi yaitu:

1. Altruism: perilaku seseorang yang membantu rekan anggota organisasi dalam menyelesaikan tugasnya.

2. Courtesy

3. Civic Virtue

4. Conscientiousness:

5. Sportmanship

\section{Kepuasan Kerja}

Kepuasan kerja adalah suatu sikap atau cara yang dimiliki dan ditunjukkan oleh seseorang mengenai tugas dari organisasinya (Vroom, 1964). Weiss, et al. (1967, dalam Rikantika, 2016) menyatakan bahwa kepuasan kerja merupakan perbandingan yang dilakukan oleh anggota organisasi 
untuk mencapai serta memelihara kesesuaian antara kondisi internal dan eksternal. Menurut Spector (1997) kepuasan kerja di definisikan sebagai salah satu perasaan yang ditunjukkan seseorang atas tugas yang telah ia kerjakan atau suatu tingkatan emosi dan refleksi dari dalam diri yang bersifat positif dan menumbuhkan perasaan menyenangkan bagi seseorang. Konsep yang sama juga dismapaikan oleh Robbins dan Judge (2017) yang menyatakan bahwa kepuasan kerja sebagai suatu perasaan positif tentang tugas dari seseorang, dimana hal itu merupakan cerminan hasil dari sebuah evaluasi karakteristik pekerjaannya. Seorang anggota organisasi yang memiliki tingkat kepuasan kerja tinggi ditunjukkan dengan perasaan- perasaan positif tentang apa yang dikerjakannya, sementara seorang aggota organisasi yang memiliki tingkat kepuasan kerja rendah, cenderung akan memiliki perasaan- perasaan negatif tentang apa yang dikerjakannya.

Menurut Robbins dan Judge (2017) kepuasan kerja memiliki 5 dimensi, meliputi:

1. Job it Self

2. Supervision

3. Pay

4. Kesempatan Promosi, hal ini dimaksudkan bahwa kesempatan promosi yang baik akan memberikan dampak yang positif terhadap organisasi.

5. Rekan Kerja, hal ini dimasudkan bahwa rekan kerja yang baik akan membuat seseoang merasa nyaman dalam bekerja.

\section{Komitmen Organisasional}

Allen dan Meyer (1990) menyatakan bahwa komitmen organisasional adalah ruang lingkup yang mengidentifikasi keterlibatan, dan loyalitas yang diekspresikan oleh seorang terhadap tugasnya, dengan demikian dapat disimpulkan bahwa komitmen organisasi merupakan suatu sikap yang ditunjukkan oleh seseorang atau individu terhadap lingkungan organisasinya dengan rasa sikap kesetian dan loyal, sehingga mereka tidak ingin meninggalkan organisasinya dalam keadaan dan alasan apapun. Porter, Steers dan Boulian (1973) mengemukakan bahwa komitmen organisasional didefinisikan sebagai bentuk kekuatan dalam mengidentifikasi keterlibatan individu dalam suatu organisasi.

Allen dan Meyer (1991) menjelaskan bahwa komitmen organisasional terdiri dari tiga komponen yaitu:

1. Komitmen afektif (Affective Commitment) merupakan perasaan emosional dan keyakinan akan nilai-nilai pada organisasi.

2. Komitmen berkelanjutan (Continuance Commitment) komitmen yang terjadi apabila seorang anggota merasa bahwa ketika meninggalkan organisasi akan mengakibatkan sebuah keburukan.

3. Komitmen normatif (Normative Commitment) adalah kewajiban untuk bertahan dalam organisasi untuk alasan moral atau etis.

\section{Pengaruh Kepuasaan Kerja terhadap Organization Citizenship Behavior (OCB)}

Merujuk pada konsep Robbins dan Judge (2017), kepuasan kerja merupakan suatu perasaan positif tentang tugas dari seseorang dan hal itu merupakan cerminan hasil dari sebuah evaluasi karakteristik pekerjaannya. Konsekuensi dari kepuasan kerja salah satunya anggota organisasi akan melakukan tugas yang melebihi dari tugas pokok yang diberikan oleh organisasi. Dengan kata lain, semakin meningkat kepuasan kerja anggota organisasi maka akan berpengaruh positif bagi OCB. Kondisi ini telah dibuktikan oleh peneliti-peneliti sebelumnya yang menguji pengaruh kepausan kerja terhadap OCB dengan hasil pengaruhnya postif dan signifikan (Hapsari, 2015; Sambung, 2011; Siregar \& Pasetio, 2015).

Berdasarkan hasil penelitian-penelitian sebelumnya, maka peneliti merumuskan hipotesis sebagai berikut: 


\section{H1: Kepuasan kerja berpengaruh positif terhadap OCB. \\ Komitmen Organisasional Mengintervensi Pengaruh Kepuasan Kerja terhadap \\ Organizational Citizenship Behavior (OCB)}

Komitmen organisasional merupakan salah satu keadaan dimana seorang anggota organisasi memiliki kesetiaan terhadap suatu organisasi. Komitmen organisasional muncul ditandai dengan kepuasan dari seseorang. Anggota organisasi yang cenderung puas terhadap organisasi akan berkomitmen tinggi, sehingga memicu tumbuhnya perilaku OCB (Bodroastuti \& Ruliaji, 2016; Prabowo \& Djastuti, 2014; Putrana, dkk, 2016). Semakin meningkatnya kepuasan kerja, maka akan meningkat pula komitmen organisasional (mengintervensi) yang kemudian sikap ini akan meningkatkan OCB dalam diri masing-masing anggota organisasi.

Berdasarkan hasil penelitian-penelitian tersebut, peneliti merumuskan hipotesis sebagai berikut:

H2: Komitmen organisasi mengintervensi pengaruh kepuasan terhadap OCB Berdasarkan rumusan hipotesis di atas, maka dapat disusun model penelitian sebagai berikut:

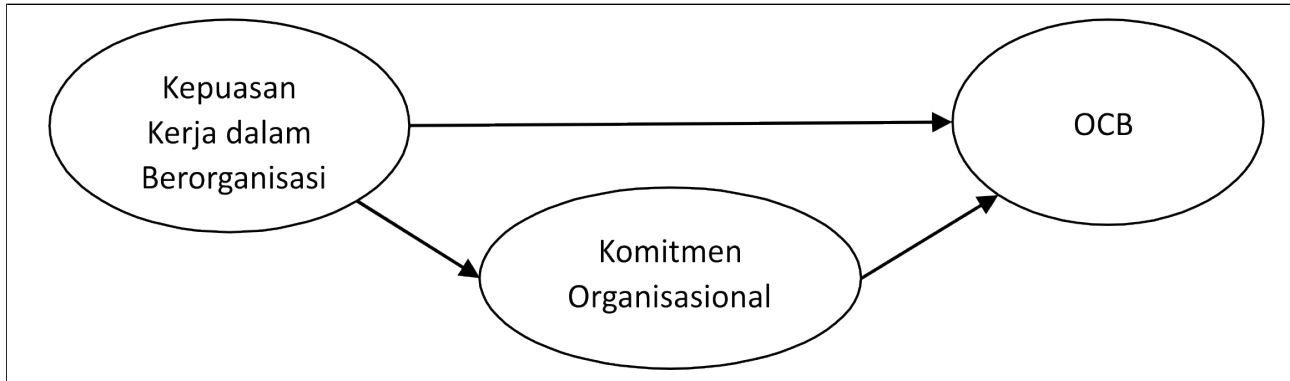

FIGURE 1 | Model Penelitian

\section{METODE PENELITIAN}

Penelitian ini mengambil objek Himpunan Mahasiswa Manajemen (HIMAMA) Fakultas Ekonomi dan Bisnis (FEB) Universitas Muhammadiyah Yogyakarta (UMY), dengan subjek penelitiannya anggota HIMAMA FEB UMY. Populasi penelitian ini yaitu anggota HIMAMA FEB UMY periode 2017-2018. Teknik pengambilan sampel yang digunakan adalah nonprobability sampling khususnya purposive sampling, yaitu teknik pengambilan sampel secara sengaja, dengan pertimbangan tertentu. Data terkumpul

merupakan data primer yang diperoleh dengan cara mendistribusikan kuesioner secara online melalui google form. Respon yang diperoleh sebanyak 102 responden.

Kepuasan kerja diukur dengan mengadopsi konsep yang dtawarkan oleh Weiss, et al (1967) dan telah dikembangkan menjadi Minesota Satisfaction Questionaires (MSQ). Alat ukur ini mengukur kepuasan kerja melalui 20 indikator, diantaranya adalah: ability utilization; achievement; activity; advancement; authority; company polices; compensation; co-workers; creativity; independence; security; social service; social status; moral value; recognition; responbility; human resource supervision; technical supervision; variety; working condition.

Komitmen organisasional didefinisikan suatu sikap yang ditunjukkan oleh seseorang atau individu terhadap lingkungan organisasinya dengan rasa sikap kesetian dan loyal, sehingga mereka tidak ingin meninggalkan organisasinya dalam keadaan dan alasan apapun Allen Meyer (1990). Ada tiga indikator yang dipakai untuk mengukur komitmen organisasional, yaitu komitmen afektif (Affectif Commitment); komitmen berkelanjutan (continuance comimitment), dan komitmen normatif (normative commitment). Sementara konsep OCB mengadopsi konsep Organ (1989) yang mengukur OCB dari lima dimensi, yaitu Altruism, Courtesy, Civic Virtue, Conscientiousness, dan Sportmanship. 
Sebelum dilakuakn pengambilan data pada responden yang ditargetkan, peneliti melakukan uji kualitas instrumen menggunakan dua macam uji, yaitu uji validitas dan reliabilitas. Berdasarkan hasil uji validitas, semua butir pernyataan dinyatakan valid dengan memenuhi syarat minimum siginifikansi yaitu di bawah 0.05 . Hasil uji reliabilitas menunjukkan bahwa nilai Cronbach alpha dari masing-masing variabel $>0.70$. Artinya kuesioner reliable atau handal untuk digunakan.

\section{ANALISIS DATA DAN HASIL}

Dari 102 sampel yang didapatkan mayoritas adalah laki-laki sebanyak 55 orang dan perempuan sebesar 47 orang. Berdasarkan hasil analisis statistik deskriptif dalam penelitian menunjukkan bahwa rata-rata responden menjawab pernyataan mengenai kepuasan kerja dalam berorganisasi pada kategori tinggi. Pada variabel komitmen organisasional rata-rata responden menjawab pernyataan pada kategori tinggi. Begitu juga pada variabel OCB rata-rata responden menjawab pernyataan pada kategori tinggi.

Sesuai dengan model yang dikembangkan pada penelitian ini, maka alat analisis data yang digunakan adalah Structural Equotion Modelling atau SEM yang dioperasikan dengan menggunakan bantuan software AMOS. Setelah data dientri dalam software, maka dilakukan penyusunan diagram jalur (path diagram) dengan hasil seperti terlihat dalam gambar 2 .

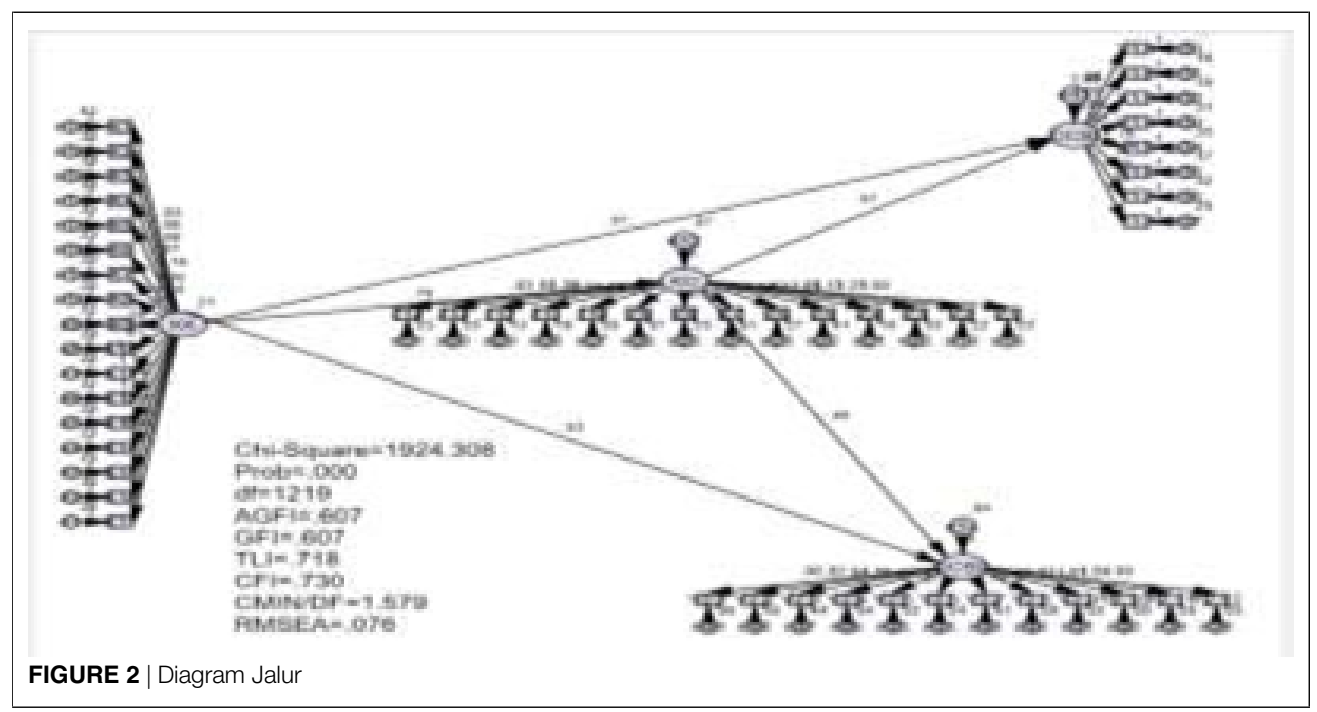

Sebelum dilakukan pengujian model, peneliti melihat ada tidaknya problem identifikasi dengan cara melihat hasil estimasi. Analisis SEM hanya dapat dilakukan apabila hasil identifikasi model menunjukan bahwa model termasuk dalam kategori over-identified. Identifikasi ini dilakukan dengan melihat nilai df dari model yang dibuat.

TABLE 1 | Computation ofdegrees of freedom (Default model)

\begin{tabular}{ll}
\hline Number of distinct sample moments: & 1326 \\
Number of distinct parameters to be estimated: & 107 \\
Degrees of freedom (1326 - 107): & 1219 \\
\hline
\end{tabular}

Hasil output AMOS menunjukan nilai df model sebesar 1219. Hal ini menunjukkan bahwa model di atas termasuk kategori over confident karena memiliki nilai df yang positif dengan jumlah yang besar. Oleh karena itu analisa data dapat di lanjutkan ke tahap selanjutnya, yaitu Evaluasi Model Struktural. Evalausi ini dilakukan dengan cara menguji normalitas dari data. Dalam output AMOS, uji normalitas dilakukan dengan membandingkan nilai CR (critical ratio) pada assessment of normality dengan kritis \pm 2 , 
58 pada level 0,01 . Berdasarkan pengujian normalitas yang telah dilaksanakan disimpulkan bahwa data tidak terdistribusi secara normal sehingga dilakukan transformasi data. Menurut Ghozali (2017), salah satu strategi untuk mengatasi data tidak normal secara multivariate adalah dengan melalui bootstrapping.

TABLE 2 | Perhitungan Bollen-Stine Bootsrap

\begin{tabular}{ll}
\hline Bollen-Stine Bootstrap & \\
The model fit better & 199 bootstrap samples \\
It fit about equally well & 0 bootstrap samples \\
It fit worsw or failed to fit in & 301 bootstrap samples \\
Bollen-Stine Bootstrap & $\mathrm{p}=.603$ \\
\hline
\end{tabular}

Hasil bootstrapping menunjukkan nilai Bollen-Stine bootsrap p sebesar 0,603 atau di atas 0, 05 yang artinya data tidak bermasalah sehingga dapat dilakukan analisis selanjutnya.

Evaluasi terhadap multivariate outliers dapat dilihat melalui output AMOS Mahalanobis Distance. Berdasarkan identifikasi outlier menunjukkan perhitungan batas akhir outlier menggunakan CHIINV dengan memasukkan probabilits 0.001 dan degree of freedom sejumlah variabel yang terukur adalah 51 item pertanyaan, kemudian melalui program excel pada sub-menu Insert - Function - CHIINV masukkan probabilitas dan jumlah variabel terukur sebagai berikut:

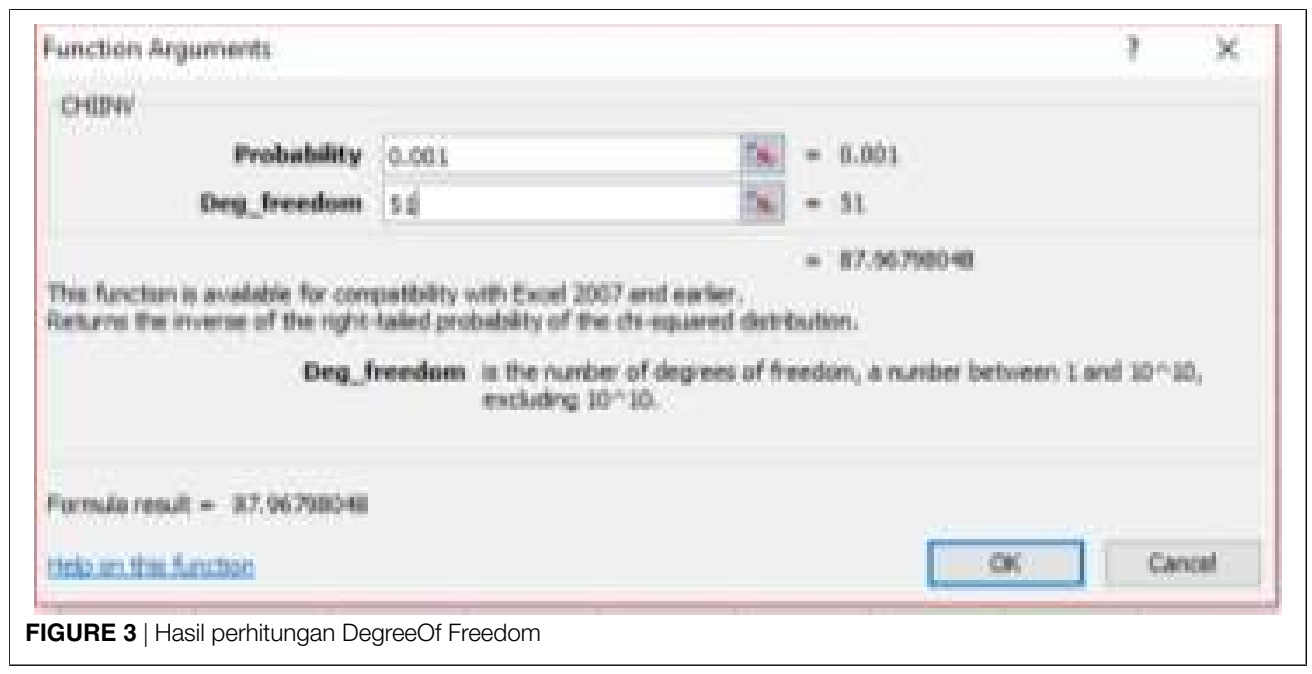

Hasilnya adalah 87.968 , artinya semua data/kasus yang lebih besar dari 87.968 merupakan outliers multivariate. Dari hasil pengujian menggunakan AMOS dapat dilihat bahwa tidak ada data yang lebih besar dari nilai $\mathbf{8 7 . 9 6 8}$ tersebut, sehingga dapat dikatakan bahwa data tidak ada yang outliers .

Setelah asumsi SEM dilakukan maka langkah berikutnya adalah pengujian dengan menggunakan beberapa indeks kesesuaian untuk mengukur model yang diajukan. Beberapa indeks tersebut yaitu:

Dengan melihat indeks lainnya yaitu RMSEA dan CMIN/DF yang nilainya telah sesuai dengan standar yang direkomendasikan dapat disimpulkan bahwa model yang dibangun pada penelitian ini adalah baik hal ini didukung dengan pernyataan Ghozali (2017) yang menyatakan bahwa jika ada satu atau dua kriterian goodness of fit yang telah terpenuhi maka secara keseluruhan model dapat dikatakan baik (good fit). Dengan demikian, dapat disimpulkan bahwa hasil pengujian goodness of fit pada model yang digunakan dalam penelitian ini menunjukkan bahwa pengujian kelayakan model sudah memenuhi syarat nilai yang telah direkomendasikan.

Uji statistik hasil pengolahan dengan SEM dilakukan dengan melihat tingkat signifikan pengaruh antar variabel yang ditunjukkan dengan melihat critical ratio (c.r) dan nilai significane probability masing-masing pengaruh antar variabel. Berikut adala output tabel pengujian hipotesis penelitian dengan menggunakan alat uji AMOS dalam bentuk output Regression 
TABLE 3 | Hasil Pengujian Goodness Of Fit Indeks

\begin{tabular}{llll}
\hline $\begin{array}{l}\text { Goodness of fit index } \\
\chi^{2} \text { (Chi- }\end{array}$ & Cut-off value & Model Penelitian & Model \\
Square) & $<1219$ & 1902.541 & Tidak Fit \\
Significant probability & $\geq 0.05$ & 0,000 & Tidak Fit \\
RMSEA & $\leq 0.08$ & 0,075 & Fit \\
GFI & $\geq 0.90$ & 0,611 & Tidak Fit \\
AGFI & $\geq 0.80$ & 0,611 & Tidak Fit \\
CMIN/DF & $\leq 2.0$ & 1,561 & Fit \\
TLI & $\geq 0.90$ & 0,723 & Tidak Fit \\
CFI & $\geq 0.90$ & 0,735 & Tidak Fit \\
\hline
\end{tabular}

Weights seperti pada tabel berikut:

TABLE 4 | Hasil Pengujian Hipotesis Pengaruh Langsung

\begin{tabular}{llllllll}
\hline & & & Estimate & S.E. & C.R. & & Hasil \\
KO & $<---$ & KK & .762 & .138 & 5.508 & $\star \star \star$ & Diterima \\
OCB & $<---$ & KO & .513 & .156 & 3.294 & $\star \star \star$ & Diterima \\
OCB & $<---$ & KK & .492 & .150 & 3.271 & .001 & Diterima \\
\hline
\end{tabular}

Dari pengolahan data diketahui bahwa nilai CR ada pengaruh dengan menunjukkan nilai di atas 1,96 untuk CR. Serta di bawah 0,05 untuk nilai P (Ghozali, 2017). Hasil analisis data juga menunjukkan adanya pengaruh langsung kepuasan kerja terhadap OCB yang ditunjukkan oleh nilai probabilitas di bawah 0,05 yaitu 0,032 . Sedangkan, untuk hasil pengujian hipotesis secara tidak langsung dapat dilihat pada tabel berikut:

TABLE 5 | Hasil Pengujian Standar Langsung

\begin{tabular}{lllll}
\hline Standardized Direct Effects & $\mathrm{KK}$ & $\mathrm{KO}$ & OCBO & OCBI \\
$\mathrm{KO}$ & .806 & .000 & .000 & .000 \\
$\mathrm{OCB}$ & .487 & .480 & .000 & .000 \\
\hline
\end{tabular}

TABLE 6 | Hasil Pengujian Standar Tidak Langsung

\begin{tabular}{lllll}
\hline Standardized Indirect Effects & KK & KO & OCBO & OCBI \\
KO & .000 & .000 & .000 & .000 \\
OCBO & .387 & .000 & .000 & .000 \\
\hline
\end{tabular}

Dari pengolahan data diketahui bahwa nilai Standardized Direct Effects sebesar 0,487 lebih besar dibandingkan nilai Indirect sebesar 0,387 dengan demikian dapat diintepretasikan bahwa variabel komitmen organisasional tidak mengintervensi pengaruh kepuasan kerja dalam organisasi terhadap OCB

\section{KESIMPULAN}

Berdasarkan hasil penelitian dapat disimpulkan sebagai berikut:

1. Kepuasan Kerja dalam Berorganisasi berpengaruh siginifikan dan positif terhadap OCB. Hal ini menunjukkan bahwa kepuasan kerja yang dimiliki oleh anggota HIMAMA FEB UMY akan memberikan respon yang positif di luar tugas dan kewajibannya yang diberikan oleh organisasi sehingga menimbulkan perilaku OCB. Hal ini didukung oleh penelitian Prabowo dan Djastuti (2014), Bodroastuti dan Ruliaji (2016), serta Putrana (2016) yang menyatakan bahwa adanya pengaruh signifikan dan positif kepuasan kerja terhadap OCB.

2. Komitmen Organisasional tidak mengintervensi pengaruh Kepuasan Kerja dalam Berorganisasi terhadap OCB. Hal ini menunjukkan bahwa kepuasan kerja dapat berpengaruh langsung terhadap OCB tanpa perlu diintervensi oleh komitmen organisasional. 


\section{KETERBATASAN DAN SARAN}

Penelitian ini menggunakan variabel dalam jumlah yang terbatas (yaitu tiga) sehingga hasil yang didapat belum sesuai denagn yang diharapkan. Saran bagi penelitian selanjutnya perlu mengidentifikasi ulang faktor-faktor yang mempengaruhi OCB dengan melibatkan variabel yang lebih banyak.

\section{REFERENSI}

1. Dewi, N. L. P. Y. A., \& Suwandana, I. G. M. (2016). Pengaruh Kepuasan Kerja terhadap Organizational Citizenship Behavior (Ocb) dengan Komitmen Organisasional sebagai Variabel Mediasi. E-Jurnal Manajemen Universitas Udayana, 5(9), 5643-5670.

2. Ghozali, Imam. (2016) Aplikasi Analisis Multivariete Dengan Program IBM SPSS 23. Badan Penerbit Undip, Semarang.

3. Ghozali, Imam. (2017) Model Persamaan Struktural Konsep dan Aplikasi Dengan Program Amos 22.0 cetakan keempat. Badan Penerbit Undip, Semarang.

4. Hapsari, S. Y. (2015). Pengaruh Kepuasan Kerja, Motivasi, Nilai Organisasi Terhadap Organizational Citizeship Behavior (OCB) (Studi Kasus Pada RS. Telogorejo Semarang). Journal of Management, 1(1), 1-13.

5. Indrayanti, D. P., \& Riana, I. G. (2016). Pengaruh Kepuasan Kerja Terhadap Turnover Intention Melalui Mediasi Komitmen Organisasional Pada PT. Ciomas Adisatwa di Denpasar. E-Jurnal Manajemen Unud, 5(5), 2727-2755.

6. Lestariningtyas, E. B. (2016). Peran Komitmen Organisasi Sebagai Variabel Intervening Antara Kepuasan Kerja dan Organizational Citizenship Behavior (OCB) Pada Karyawan PT. Coca-Cola Distribution Indonesia, Surabaya. Jurnal Ilmu Manajemen (JIM), 4(3), 1-14.

7. Meyer, J. P., \& Allen, N. J. (1991). A three-component conceptualization of organizational commitment. Human resource management review, 1(1), 61-89.

8. Organ, D. W., \& Moorman, R. H. (1993). Fairness and organizational citizenship behavior: What are the connections?. Social Justice Research, 6(1), 5-18.

9. Organ, D. W., \& Ryan, K. (1995). A meta-analytic review of attitudinal and dispositional predictors of organizational citizenship behavior. Personnel psychology, 48(4), 775- 802.

10. Prasetio, A. P., Siregar, S., \& Luturlean, B. S. (2015). The effects of job satisfaction and organizational commitment on organizational citizenship behavior. Jurnal Siasat Bisnis, 19(2), 99-108.

11. Puspitawati, N. M. D., \& Riana, I. G. (2014). Pengaruh kepuasan kerja terhadap komitmen Organisasional dan kualitas layanan. Jurnal Manajemen Strategi Bisnis dan Kewirausahaan, $8(1), 68-80$.

12. Putrana, Y., Fathoni, A., \& Warso, M. M. (2016). "Pengaruh kepuasan kerja dan komitmen organisasi terhadap organizational citizenship behavior dalam meningkatkan kinerja karyawan pada PT. Gelora Persada Mediatama Semarang". Journal of Management, 2(2), 114.

13. Prabowo, A., \& Djastuti, I. (2014). Analisis Pengaruh Kepemimpinan Transformasional dan Kepuasan Kerja terhadap Organizational Citizenship Behavior (OCB) dengan Komitmen Organisasi sebagai Variabel Intervening (Studi pada Perawat RSUP Dr. Kariadi, Semarang) (Doctoral dissertation, Fakultas Ekonomika dan Bisnis).

14. Pradhiptya, A. R. (2018). Pengaruh Kepuasan Kerja Terhadap Organizational Citizenship Behaviour (Ocb) Dengan Mediasi Komitmen Organisasional. BISMA (Bisnis dan Manajemen), 6(1), 50-58.

15. Robbins, S. P \& Judge, T. P (2017) Perilaku Organisasi: Organizational Behavior. Edisi 16. Salemba Empat : Jakarta Selatan.

16. Sambung, R. (2011). Pengaruh Kepuasan Kerja Terhadap OCB-I Dan OCB-O Dengan Dukungan Organisasi Sebagai Variabel Moderating (Studi pada Universitas Palangka Raya). Jurnal Analisis Manajemen, 5(2), 77-90. 
17. Sari, P. K., \& Soliha, E. (2017). Komitmen Organisasinal dan OCB sebagai pemediasi pada pengaruh gaya kepemimpinan transformasional sebagai kinerja pegawai (Studi pada Dinas Pertanian dan Kehutanan Kabupaten Rembang). Jurnal Manajemen dan Bisnis Indonesia, 3(3), 398-426.

18. Sekaran, U. 2017. Metodologi Penelitian Untuk Bisnis. Salemba Empat: Jakarta.

19. Susilo, P. J., Minarsih, M. M., \& Warso, M. M. (2016). Pengaruh Komitmen Afektif, Komitmen Berkelanjutan dan Komitmen Normatif terhadap OCB pada kayawan SPBU 44.502. 12 Semarang. Journal of Management, 2(2).

20. Williams, L. J., \& Anderson, S. E. (1991). Job satisfaction and organizational commitment as predictors of organizational citizenship and in-role behaviors. Journal of management, 17(3), 601-617.

21. Yulianto, N. A. B., Noermijati, N., \& Sudiro, A. (2016). Peran Komitmen Organisasional dalam Memediasi Pengaruh Kepuasan Kerja terhadap OCB Islam (Studi pada BMT Maslahah Sidogiri). Jurnal Aplikasi Manajemen, 14(4), 747-75

Conflict of Interest Statement: The authors declare that the research was conducted in the absence of any commercial or financial relationships that could be construed as a potential conflict of interest.

Copyright (C) 2020 Kurnia Puji Rahayu and Ani Qurdiana. This is an open-access article distributed under the terms of the Cre- ative Commons Attribution License (CC BY). The use, distribution or reproduction in other forums is permitted, provided the original author(s) and the copyright owner(s) are credited and that the original publication in this journal is cited, in accordance with accepted academic practice. No use, distribution or reproduction is permitted which does not comply with these terms. 